\title{
VIDAS QUE SEGUEM: NARRATIVAS FICCIONAIS DE JOVENS VIVENDO COM HIV/AIDS
}

\author{
LIFE GOES ON: FICTIONAL NARRATIVES WITH YOUNG PEOPLE LIVING WITH HIV/AIDS. \\ VIDAS QUE SIGUEN: NARRATIVAS FICCIONALES CON JÓVENES VIVIENDO CON VIH / SIDA
}

\author{
Emilene Araujo de Souza* \\ Luciana Kind**
}

\begin{abstract}
RESUMO
Esse artigo se trata de uma pesquisa que teve por objetivo compreender os modos de narrar o viver com HIVlaids de jovens soropositivos. Partese da ideia de performatividades do self, contribuição teórica do estudo de narrativas. A estratégia metodológica consiste de observação de participantes e entrevistas narrativas com 12 jovens soropositivos com idades entre 22 e 29 anos. O material foi submetido à análise dialógica/performática de narrativas, e serviu como suporte para a construção de narrativas ficcionais. Essa estratégia visa "embaralhar" os fragmentos das narrativas e criar "colagens", que são baseadas em fatos reais; porém devem ser lidas como ficção. Conclui-se que é necessária a ampliação da circulação de informações sobre o HIV/aids entre os jovens. Além disso, observa-se que as narrativas ficcionais se apresentam como uma alternativa para a exploração de novas formas de comunicação, possibilitando a inclusão das singularidades da vida após o diagnóstico.
\end{abstract}

Palavras-chave: Jovens. HIV/aids. Narrativas ficcionais. Análise dialógica/ performática.

\section{ABSTRACT}

This paper presents a study that aimed to understand the ways of narrating living with HIV/aidsinvolving young people. The idea of performativity of the self was a departing point, as a theoretical contribution from the narrative inquiry. The methodological strategy was composed of participant observation and narrative interviews with 12 seropositive youngsters between the ages of 22 and 29 years. The material was submitted to dialogic/ performance narrative analysis and was the basis for the construction of fictional narratives. This strategy consists of "shuffling" the fragments of the narratives and creating "collages", which are based on real facts, but are supposed to be read as fiction. We conclude that it is necessary to expand

\footnotetext{
* Mestranda em Psicologia na Pontifícia Universidade Católica de Minas Gerais; bolsista CNPq. E-mail: emilenedesouza@gmail. com

** Doutora em Saúde Coletiva (IMS/UERJ), com pós-doutorado em Psicologia Social (UFMG). Professora do Programa de Pósgraduação em Psicologia da Pontifícia Universidade Católica de Minas Gerais. E-mail: lukind@gmail.com
} 
the circulation of information about HIV/aids among young people and that fictional narratives are presented as an alternative for the exploration of new forms of communication that include the singularities of life after diagnosis.

Key-words: Youth. HIV/aids. Fictional Narratives. Dialogic/Performative Analysis.

\section{RESUMEN}

Ese artículo presenta unestudio que objetivócomprenderlos modos de narrar elvivircon VIH/sida involucrándosejóvenesseropositivos. Se parte de laidea de performatividadesdelself, contribución teórica de losestudios de narrativa. La estrategia metodológica fuecompuesta de observación participante y entrevistas narrativas con 12 jóvenesseropositivosconedades entre 22 y 29 años. El material fue sometido alanálisis dialógico/performático de narrativas y sirvió como soporte para laconstrucción de narrativas ficcionales. Esta estrategia consiste en "barajar" los fragmentos de las narrativas y crear "collages", que se basanenhechosreales, pero deben ser leídos como ficción. Concluimos que esnecesario que se amplíelacirculación de informaciones sobre el VIH/sida entre losjóvenes y que las narrativas ficcionales se presentan como una alternativa para laexploración de nuevas formas de comunicación que incluyanlas singularidades de la vida despuésdel diagnóstico.

Palabras clave: Jóvenes. VIH/sida. Narrativas ficcionales. Análisis dialógico/ performático.

\section{INTRODUÇÃO}

"[. . .] eram jovens vibrantes e, de repente, foram arrebatados" (Cogan \& France 2012, 13:15). É dessa forma que Barbara Starrett, médica estadunidense que esteve na linha de frente do tratamento a pessoas com Síndrome da Imunodeficiência Adquirida (HIV) desde o início da epidemia nos anos de 1980, descreve as muitas pessoas que foram infectadas pelo vírus na ocasião da chegada da epidemia. Diferentemente de outras doenças sexualmente transmissíveis existentes na época, não havia tratamento para o vírus HIV. Além desse fator, os efeitos da desinformação e os impactos diante da realidade de um vírus letal geraram medo, rejeição, discriminação e preconceito em relação àqueles que apresentavam os sintomas da aids e àqueles pertencentes ao "grupo de risco", como era denominado na época (Ayres, França Júnior, Calazans, \& Saletti, 2000) $)^{1}$.

\footnotetext{
1 Ayres et al. (2000) pontuam que o conceito de grupo de risco, e, posteriormente, o de comportamento de risco, guiaram os primeiros anos da resposta a epidemia de HIV/Aids. Atualmente trabalha-se com o conceito de população-chave, pois entendese que toda a população é vulnerável ao contágio pelo vírus HIV.
} 
No Brasil, há registros de relatos dos primeiros casos da doença apenas em 1983 e, no fim desse mesmo ano, casos de aids já eram registrados em diferentes capitais do país. Medo, morte, discriminação, violações de direitos, ausência de ação do Estado e desinformação faziam parte do cotidiano de pessoas com HIV/ aids (Galvão, 2000). Foi em 1996, já na segunda década da epidemia, que a terapia antirretroviral (TARV), também chamada de "coquetel", chega ao Brasil. Junto à terapia, foram disponibilizados medicamentos na rede de saúde pública, reduzindo expressivamente o número de mortes em consequência da aids, o que seria, então, um "divisor de águas" (Greco, 2016, p. 1556).

O enfrentamento da epidemia de aids está em sua quarta década - período considerado entre os anos 2010 e 2019. No contexto atual, com as possibilidades de tratamento através da terapia antirretroviral (TARV), a infecção pelo vírus HIV não representa mais imperiosamente o adoecimento por aids ou a morte, aproximando o status dessa doença ao das enfermidades crônicas (Organização Mundial de Saúde [OMS], 2003). A investigação de sorologia por meio de fluido oral - disponíveis inclusive em farmácias da rede privada de algumas cidades brasileiras -, e novas estratégias de prevenção, como a Profilaxia pós-exposição $(\mathrm{PEP})^{2}$ e a Profilaxia pré-exposição $(\mathrm{PrEP})^{3}$, já são uma realidade; são inovações que surgem atreladas às novas discussões sobre prevenção e promoção da saúde associadas ao HIV/aids.

Erradicar a epidemia da aids até 2030 foi um dos compromissos assumidos pelos Estados-membros da Organização das Nações Unidas (ONU) em 2016. O acordo apresenta metas a serem alcançadas até o ano de 2020 conhecidas como 90-90-90, que se referem ao índice de pessoas vivendo com HIV, ou seja, $90 \%$ deverão saber que têm o vírus, $90 \%$ dessas receberão terapia antirretroviral ininterruptamente e $90 \%$ terão supressão viral (Programa das Nações Unidas sobre HIV/AIDS [UNAIDS], 2016). O Brasil é signatário desse acordo que, além das metas já explicitadas, apresenta como uma de suas resoluções:

Enfatizar que o envolvimento significativo de pessoas que vivem com, em risco de e são afetadas pelo HIV e populações em maior risco de HIV facilita a obtenção de respostas mais eficazes a AIDS, e que as pessoas que vivem com, com risco e afetadas pelo HIV devem desfrutar igualmente todos os direitos humanos e gozar de participação igualitária na vida civil, política, social, econômica e cultural, sem preconceito, estigma ou discriminação de qualquer natureza ${ }^{4}$ (Organização das Nações Unidas [ONU], 2016).

2 A PEP (sigla para a expressão em inglês post exposureprophylaxis) se insere no âmbito da prevenção combinada e consiste na prescrição de medicamentos antirretrovirais em até 72 horas após o contato do paciente com o vírus HIV. O tratamento dura 28 dias e o atendimento é considerado de emergência pelo Ministério da Saúde.

3 A profilaxia pré-exposição ao HIV (PrEP, sigla correspondente a pre-exposureprophylaxis) é uma estratégia de prevenção que envolve a utilização diária de um medicamento antirretroviral (ARV) por pessoas não infectadas, com o objetivo de reduzir o risco de aquisição do HIV através de relações sexuais. Mais informações no site http://prepbrasil.com.br/

4 "Emphasize that the meaningful involvement of people living with, at risk of, and affected by HIV and populations at higher risk of HIV facilitates the achievement of more effective AIDS responses, and that people living with, at risk of, and affected by HIV should enjoy equally all human rights and enjoy equal participation in civil, political, social, economic and cultural life, without prejudice, stigma, or discrimination of any kind."(ONU, 2016). 
No entanto, a curva ascendente de novas infecções pelo vírus HIV entre a população jovem ${ }^{5}$ é uma preocupação para as estratégias de enfrentamento da epidemia de HIV/aids no Brasil e no mundo. A epidemia de HIV/aids que, na sua origem, foi relacionada à morte, ao sexo e às drogas se alastrou carregada de estigmas que permeiam as respostas sociais associadas às pessoas vivendo com HIV/aids (Mann, 1987; Parker \& Aggleton, 2001). Além disso, as possíveis formas de viver com HIV/aids foram e ainda hoje são atravessadas por singularidades políticas, sociais, etárias, de classe e de gênero.

O aumento do número de jovens infectados pelo HIV, a chamada "Juvenilização" da aids, ocorre em um contexto sociocultural no qual as crianças infectadas por transmissão vertical tornam-se jovens e no qual há também um aumento de novas infecções por via sexual. (Rios, Pimenta, Brito, Terto Júnior, \& Parker, 2002). Nesse cenário, esses jovens passam a ser uma preocupação para os agentes públicos de saúde (Cunha, 2012). Sehneme et al (2015) realizaram um estudo qualitativo com 15 jovens e concluíram que aqueles que estão vivendo com HIV têm a percepção de que estão saudáveis. Em visto disso, as estratégias para a redução da propagação do vírus devem estar centradas no autocuidado e na redução do preconceito e do estigma na sociedade. Conforme os pesquisadores, "na pluralidade do processo de adolescer com aids, parece que as singularidades desse processo têm adquirido menos visibilidade no emaranhado das investigações que privilegiam meramente as questôes clínicas e epidemiológicas" (Sehnem et al., 2015). Entende-se que, a despeito de os/as jovens não enfrentarem desafios como aqueles defrontados pelos que viveram com HIV/aids no início da epidemia - tais como a falta de tratamento e a pouca expectativa de sobreviver à infecção -, há outras nuances sobre o viver com HIV/aids no contexto atual que moldam suas formas de estar no mundo. Questionamos, então, como o viver com HIV/ aids compõe as narrativas de jovens soropositivos sobre sua experiência de vida.

Neste artigo, apresentamos uma pesquisa qualitativa cujo objetivo foi compreender os modos de narrar o viver com HIV/aids na construção de narrativas ficcionais com jovens soropositivos. As narrativas ficcionais (Reigota, 1999) se configuram como uma proposta analítico-descritiva de "embaralhar" os fragmentos das narrativas e criar "colagens", que são baseadas em material empírico e experiencial das pesquisadoras, porém montadas para serem lidas/ vistas como ficção. Dessa forma, esse recurso estético-metodológico possibilita

\footnotetext{
5 O conceito de juventude é estudado no campo acadêmico a partir de diversas perspectivas, apresentando uma característica de pluralidade em suas teorizaçôes (Abramo, 1997; Pais, 1990; Erickson, 1987), ampliando as análises possíveis para além de determinações etárias. No entanto, consideramos que foge ao escopo deste texto aprofundar as questões relativas às discussōes sobre juventude. Nesta pesquisa, a discussão toma como ponto de partida as teorizações de Debert (2000) ao apontar que as categorias etárias não são dadas por natureza, mas sim por representações sobre as etapas da vida como a velhice, a infância, a adolescência e a juventude que possuem significados particulares em diferentes contextos históricos, culturais e sociais. Optamos pela utilização do termo "jovens", a fim de seguir o que se encontra de forma majoritária nas políticas públicas voltadas para pessoas vivendo com HIV com idades entre 15 e 29 anos.
} 
"usar informações sem ferir ou delatar" e "trazer ao debate público-científico as situaçôes concretas da vida complexa e fragmentada da nossa época" (Reigota, 1999, p. 74). Leavy (2013) fala do potencial transformador da ficção, uma vez que esta permite o acesso a mundos imaginários ou possíveis que convidam tanto leitor quanto o escritor a reexaminar seus próprios mundos, além de possibilitar a abordagem de temas complexos e convidar à leitura de forma agradável. A proposta das narrativas ficcionais possibilita compartilhar histórias sobre o viver com HIV/aids, tomando o sigilo à identidade dos jovens que participaram deste estudo como experiência ético-estético-política.

\section{METODOLOGIA}

Jovchelovitch e Bauer (2007) afirmam que a entrevista narrativa apresenta o potencial de explorar modos de comunicação cotidiana, que consistem nas posições intersubjetivas de contar e ouvir histórias. Para os autores, "a narrativa não é só uma listagem de acontecimentos, mas uma tentativa de ligá-los tanto no tempo, como no sentido.” (Jovchelovitch \& Bauer, 2007, p. 92). Diferentemente do modelo "pergunta-resposta", que se aproxima de uma estrutura mais imposta pelo entrevistador, a entrevista narrativa tem foco na perspectiva do informante. A recomendação dos autores é pensar uma questão inicial, geradora de narrativas, e conduzir a entrevista com o mínimo de interrupções possíveis. A questão geradora usada neste estudo foi: conte-me como descobriu que estava infectadola pelo HIV e como essa notícia impactou sua vida desde então.

Como estratégia central de produção de material empírico, foram realizadas 12 entrevistas narrativas com jovens entre 22 e 29 anos que vivem com HIV/aids. Não houve restrição de gênero, forma de infecção, condição social ou tempo de diagnóstico, objetivando alcançar uma ampla diversidade de histórias narradas.

Para a realização da primeira entrevista, utilizamos, como estratégia de entrada no campo, o contato com um jovem que frequentava a Comissão Municipal de IST/aids e Hepatites Virais de Belo Horizonte ${ }^{6}$. A partir daí, aplicamos a estratégia da "bola de neve", pressupondo que os participantes iniciais indicariam novos participantes e, assim, sucessivamente, para chegar a outros/as entrevistados (Baldin \& Munhoz, 2011). No entanto, a situação da escolha do sigilo da sorologia pela quase totalidade das/dos entrevistados/as, limitava-os/as em relação a indicação de outras pessoas para a entrevista. Frente a isso, realizamos divulgaçóes a respeito da pesquisa na rede pessoal de contato das pesquisadoras, bem como divulgação na Rede Mundial de Jovens Vivendo e Convivendo com HIV/aids, resultando em outras participações na pesquisa.

6 Tal comissão é uma instância consultiva, constituída em 1996, que busca estabelecer um diálogo na construção e consolidação da política municipal de IST/Aids, da qual as autoras participam como representantes de instituiçóes formadoras. 
As entrevistas foram transcritas e submetidas à análise que, para o estudo, seguiram os preceitos da perspectiva dialógica/performática (Riessman, 2008). Em um segundo momento, a análise dos dados empíricos adveio da própria construção das narrativas ficcionais (Reigota, 1999), ao passo que, ao recompor as narrativas em diálogo com os participantes, foi possível identificar e selecionar as tramas apontadas como relevantes, bem como aquelas que, por alguma razão, são vetadas. Percebemos que essas estratégias de análise foram adequadas para a pesquisa sobre o cotidiano de jovens que vivem com HIV/aids, em função da possibilidade de incluir tanto a influência do contexto social quanto a subjetividade da própria pesquisadora na análise dos dados construídos.

Riessman (2008) apresenta a análise dialógico/performática como uma abordagem que inclui a dimensão da performatividade do self na narrativa. Segundo a autora, há uma finalidade específica nas performances encenadas para se comunicar o que deseja. As diferentes formas de expressão dos atores sociais são construídas dialogicamente em um contexto específico de interlocução entre entrevistadora e entrevistado/a e estão em estreita relação com o contexto histórico e cultural no qual as narrativas são produzidas. Todo o ambiente de produção da narrativa - do qual a entrevistadora é parte ativa -, afeta as "performances" ou as formas de narrar as histórias. No processo de análise dialógico/performática, a pesquisadora se debruça sobre o material empírico e, ao interpretá-lo, questiona para "quem", "quando" e "por quê" os enunciados são produzidos. Admite-se haver uma intenção intrínseca em cada narrativa. As histórias são pensadas como "artefatos sociais" que falam tanto da sociedade e da cultura em que elas são produzidas quanto do próprio sujeito ou do grupo (Riessman, 2008, p. 105).

Riessman (2008) aponta alguns recursos linguísticos performáticos comumente utilizados pelos narradores ao contarem suas histórias. No processo de análise, a identificação desses recursos auxilia a pesquisadora a mapear as intenções presentes nas narrativas, uma vez que tais recursos linguísticos são considerados como meios que os narradores utilizam para sustentar determinadas performances. Foram observados, no processo de análise, os seguintes elementos performativodialógicos: discurso direto, repetição, ventriloquismo, uso de sons expressivos, uso performático de tempos verbais, interlocução, inflexão de voz, interrupções da narrativa e sobreposição de discursos. Um outro elemento que guiou a análise foi a interpretação do self preferido. De acordo com Riessman (2008), é possível que vários "eus" surjam nas narrativas. No entanto, a apresentação do selfpreferido diz respeito ao ato, consciente ou não, do narrador eleger e apresentar um aspecto predileto de sua personalidade-identidade. A postura interpretativa na análise dialógica/performática busca identificar os recursos linguísticos utilizados pelos narradores, bem como a função que desempenham na narrativa. 
A análise dialógica performática do material empírico permitiu contextualizar e mapear os diferentes modos de expressão e, na interpretação das narrações, situar as subtramas sobre o viver com HIV/aids que emergem com maior carga afetiva, além de identificar o self preferencial presente nos contextos narrativos (Riessman, 2008, p. 105).

\section{VIDAS QUE SEGUEM: DITOS E NÃO DITOS SOBRE O VIVER COM HIV/AIDS}

A identificação do self preferencial, feito a partir da análise dialógicaperformática das entrevistas, trouxe informaçōes relevantes sobre a forma como as/os narradores/as escolheram fazer sua apresentação pessoal diante da pesquisadora no momento de produção das entrevistas. As principais formas de se apresentar reforçam, como performance preferencial, selfs mais ou menos conectados com a experiência de se viver com o HIV/aids. Basílio e Márcio, como exemplos disso, reiteram em variados momentos a disponibilidade para o cuidado com o outro. Rafaela apresenta-se como militante, como alguém que ocupa espaços políticos afirmativamente. Destacamos, entre as performances de selfpreferido, os fragmentos narrativos de Fabrício a Arthur.

Você tenta, você tenta viver normal. Você tenta ver que sua vida está normal, mas todo dia de manhã, na hora que você acorda, você tem que tomar os remédios, você relembra. [. . .] Então você lembra, você pega o... a caixinha, conta os remédios, né? Toma, ingere eles e fala né... é por isso, de novo, vou tomar de novo, mas tem que tomar. (Fabrício, 23 anos, diagnosticado há 8 meses).

No primeiro momento é um impacto, depois a gente começa a entender sobre a doença e ver que tem tratamento, que a gente vive normal, [. . . Eu hoje pensar em futuro eu só penso mais em curtir a vida, fazer o que eu não fiz ainda, pra quando a senha chegar, eu falei, você fala assim, pra mim deu, já fiz tudo que eu tenho vontade fazer né? (Arthur, 25 anos, diagnosticado há 1 ano).

Nos dois fragmentos, observamos a ideia de "normalidade", mas, enquanto Fabrício explicita a relação com o uso dos antirretrovirais como elemento que se interpõe a uma vida "normal", Arthur acentua o "curtir a vida" como a direção que o conforta. Fabrício se apresenta como alguém que carrega um fardo; Arthur assume uma postura de despreocupação diante do diagnóstico.

As histórias de vida, perspectivas de futuro, relações familiares, questões afetivo-sexuais, embora apresentem similaridades entre as/os participantes em determinadas situações, são marcadas por processos pessoais. Dessa forma, diferentes performances são apresentadas pelas/pelos narradores enquanto ato 
intencional de comunicação. Contudo, conforme exprime Tamboukou (2016), "as narrativas são psicossociais por excelência", através das narrativas individuais e subjetivas das/dos entrevistados/as é possível apreender elementos históricos, culturais e temporais que permeiam as vidas dos narradores (Tamboukou, 2016, p. 69)

Neste estudo, percebemos como as performances sustentaram, na maioria das vezes, posturas de superação e resiliência, muitas delas embasadas na narrativa de "vida normal" após a infecção pelo HIV ou adoecimento por aids. Como algo comum às narrativas, a "normalidade" do viver com HIV organizou o discurso dos jovens. Squire (2010) alerta que o processo de naturalização do HIV, com base na medicalização, trouxe o viver com HIV para a ordem natural da vida das pessoas, além de ignorar conteúdos importantes presentes no contexto da infecção, como:

a) discussōes sobre a redução de investimentos na área do HIV/aids;

b) o impacto nas relações;

c) a escolha de viver o diagnóstico de forma sigilosa, ou não; e

d) as adversidades ainda existentes no contexto de recebimento do diagnóstico.

Foi possível observar esse panorama durante o estudo, ao passo que os temas apontados pela autora surgiram nas narrativas, embora ocorrendo apenas em tramas paralelas, por vezes, ampliadas a partir de algum questionamento da entrevistadora. Outra indicação desse cenário foi a ausência de alguns temas nas narrativas, tais como o investimento em pesquisas ou perspectivas de cura. O sexo foi outro tema pouco abordado pelas/pelos entrevistados. Com exceção de um participante que falou espontaneamente sobre o tema, o sexo, quando abordado, foi tratado de forma indireta ou com foco nas falas de prevenção, do uso ou não do preservativo, conforme é possível constatar na passagem a seguir:

Eu acho que foi uma dessas pessoas que encontrei em um aplicativo que veio que... que... que... que eu me infectei. Eu tenho... eu tenho pra mim que foi uma dessas pessoas que... que eles usam termos assim, ah eu só vou transar sem camisinha, já fala no aplicativo que quer só transar sem né? Usam os termos tipo assim, aí não sei o que, desculpa fico até meio... fico assim... [. . . É uma coisa que eu fico até sem graça de falar (risos), mas é o que se fala em alguns aplicativos. Homem em aplicativo, você fala muita putaria, né? Então, assim acaba que fica uma coisa fácil, o tesão aumenta e você vai faz. E eu acho que o aplicativo ajudou muito sim. (Fabrício, 23 anos, diagnosticado há 8 meses) 
Saber eu sabia do HIV, mas não sabia que era tão fácil pegar, da noite pro dia, então, quando a gente está com pouco de álcool na cabeça, ou um pouco mais, a gente assim, a gente não pensa duas vezes em fazer... deixar de fazer aquilo pelo fato de não ter o preser... o preservativo. Então, a gente acaba fazendo e a consequência pode vir depois. Então eu acho que foi numa dessas que eu entrei, porque eu sempre usava preservativo, foi um dia que eu estava muito bêbado, não sei, eu não consigo lembrar. Aí assim, mas eu não culpo também ninguém. (Arthur, 25 anos, diagnosticado há 1 ano)

O abuso de álcool e outras drogas está relacionado ao uso inconsistente de preservativo e é citado como fator de vulnerabilidade ao HIV/aids e outras ISTs em diversos estudos (Nelson et al., 2016; Pereira et al., 2012). As conclusões dos estudos indicam a necessidade do incremento de estratégias de redução de danos, como o incentivo da autorresponsabilidade e autoproteção dos jovens, o que aponta para o aspecto da retórica do sexo com responsabilidade na esfera da prevenção. Baptista, Maciel, Caldeira, Tupinambás e Greco (2012) também abordaram o tema, porém, levantaram ser fundamental a atuação integrada de autoridades sanitárias e de toda a sociedade para efetiva redução de vulnerabilidade tanto individuais quanto coletivas. Nesse caso, é importante ressaltar que apesar de a lei restringir o acesso aos maiores de 18 anos, sabe-se que a restrição não é cumprida de forma efetiva no país.

Um tema recorrente nas narrativas foi a associação do HIV com morte e os consequentes impactos do recebimento do diagnóstico. As narrativas revelaram que as informações e o discurso de vida normal se estabeleceram após um primeiro momento, no qual há, muitas vezes, uma certeza da morte precoce. $\mathrm{O}$ trecho narrativo a seguir apresenta essa perspectiva:

Se eu pegasse HIV hoje, eu estaria como todo mundo que se descobre e encontra a gente pra conversar, louco, achando que vai morrer amanhã. Ainda é isso. Eu apoio pessoas desde 2014,2 1015 até agora, 2006, até 2017, e a fala é a mesma. Eu vou morrer amanhã, não vou? Não, calma, espera aí. Mas, como assim, mas eu vou ficar amarelo, ah, mas eu vou ficar magro, não sei o que. A visão é sempre a mesma, não muda, não muda! Fala que tem informação, é mentira, porque não tem, não tem essa informação. Tem essa informação de ah, use camisinha. No... no 1 de dezembro, ou no carnaval, acabou, não se fala mais nada. [. . .] Então, quem tem não fala, então, assim, não se tem uma informação de fato que é viver com HIV. Então, é isso. Então, falar, ah, mas, o jovem está se infectando, porque acha que está em tratamento. Não, os jovens chegam achando que vão morrer amanhã. Ele não sabe que tem tratamento. Isso é mentira, isso é fala de... de adulto, que, que acha que está passando informação use camisinha correta. (Rafaela, 26 anos, diagnosticada há 24 anos)

Informações acerca de tratamentos e procedimentos a serem seguidos após o resultado positivo para o HIV também não eram de conhecimento dos/das 
narradoras antes da infecção, o que reforça a necessidade de reflexão sobre a qualidade da circulação de informaçôes sobre o HIV/aids e outras ISTs entre os jovens. Val et al. (2013) realizaram um estudo quantitativo com o objetivo de comparar o conhecimento de estudantes do ensino médio de duas escolas estaduais públicas em São Paulo a respeito do HIV/aids entre os anos de 1999 e 2010. A pesquisa verificou que, em dois momentos específicos, os jovens não se consideravam vulneráveis ao HIV e tinham dúvidas sobre conhecimentos corretos acerca do HIV/aids.

Com isso em mente, ressaltamos a importância da reflexão sobre como são construídos os espaços de diálogo com jovens. A possibilidade de discussão de temas como sexo, sexualidade, prazer, erotização é um desafio que esbarra também nos contornos sociais de moralidade e nos discursos religiosos. Subtramas com esse tema emergiram em narrativas de participantes deste estudo, que relataram como determinados discursos religiosos influenciaram comportamentos, relacionamentos e a vivência da sexualidade, conforme se lê no seguinte fragmento narrativo:

Aí minha mãe ia na igreja evangélica. Aí sempre, desde pequeno eu ouvi falar: gostar da pessoa do mesmo sexo é um espírito ruim. É um, desculpa a palavra, um demônio. Sempre ouvi falar isso. Ah isso sempre me travou a contar pra minha família, sabe? E aí, eu fui crescendo, fui olhando pros rapazes, fui tendo interesse, até que eu tive contato beijei outro rapaz, mas pensei, não, não posso, não posso sentir isso, que isso não é de Deus, é do diabo. Isso é... aí eu peguei, conheci uma menina, aí eu comecei a namorar essa menina, tinha meus 15 pra 16 anos e minha família conhecia ela, a família dela me conhecia, sabe? Aí depois foi passando o tempo, assim, eu via que eu... eu não queria aquilo. Aí, aí eu mudei de casa e isso foi uma desculpa pra eu terminar com ela. Aí nós terminamos. Aí eu sempre vivi uma vida escondida, sempre escondi de todo mundo. Aí ficava com as pessoas, mas, assim, escondido, sabe? Sabe, não gostava de me identificar, não gostava de estar perto de muito homossexual, porque eu tinha medo das pessoas... das pessoas achar que eu era, saber que eu era, porque eu estava perto dele, sabe? Aí eu falei: ah, vou na igreja, vou ficar firme na igreja. Aí eu fui na igreja, tentei me espiritualizar, sabe? Aí eu não consegui, eu nunca conseguia é... parar de ter desejo por rapaz. Não aquele desejo obsessivo, aquela impulsão, mas a gente sabe o que atrai a gente, né? Aí, aí eu sempre me escondia. Aí fiquei muito tempo na igreja, fiquei numa faixa de três a quatro anos na igreja, sem me relacionar com ninguém, mas sempre ouvindo: homossexualismo é do capeta.(Beto, 23 anos, diagnosticado há 7 meses)

A complexidade e os desafios que envolvem as temáticas do preconceito despontam também nas decisóes sobre contar ou não contar e para quem contar a respeito da sorologia positiva para o HIV. Narrativas de dois participantes deste estudo trouxeram relatos de impasses na manutenção de sigilo da sorologia, como dificuldades de justificar ausências do trabalho para realização de exames periódicos e interrupção da ingestão de medicação em ambientes que podem 
trazer algum risco da descoberta da sorologia. Outros participantes que vivem as sorologias de forma sigilosa descreveram estratégias usadas para lidar com questionamentos acerca das medicações e rotinas de tratamento, como por exemplo, associá-los a outras doenças, descartar as embalagens das medicações e eximir-se de fazer quaisquer comentários sobre o tema em função do risco de serem identificados como pessoas que vivem com HIV/aids.

Outro ponto recorrente nas narrativas foi a relação com a revelação da sorologia em relacionamentos afetivo-sexuais. A maioria das/dos participantes entende não haver necessidade de revelar o diagnóstico no caso de relações esporádicas, embora considerem fundamental no caso de relacionamentos fixos, em que surge o receio de não serem aceitos pela/pelo parceiro/a. Como uma das soluções, alguns participantes relataram desejar um relacionamento fixo com parceiro também soropositivo, como forma de evitar o preconceito. Ribeiro, Padoin, Paula e Terra (2013), realizaram uma pesquisa de cunho qualitativo com 16 adolescentes da região sul do país com o objetivo de analisar seus cotidianos terapêuticos. A pesquisa identificou que os adolescentes temem que sua sorologia seja descoberta e que esse fato leve a situações de preconceito e discriminação. Por essa razão, optam por manter sigilo de suas sorologias, especialmente entre amigos. O estudo alerta que tal postura reduz a rede de apoio aos adolescentes e pode influenciar o desenvolvimento, a manutenção da saúde e as relações afetivas dos adolescentes.

Rose (2013) aponta os "projetos de cidadania" ou as maneiras como autoridades consideram algumas pessoas como potenciais cidadãos e, com base nisso, criam formas de interferir (Rose, 2013, p. 189). Para o autor, "as pressuposições biológicas, explícita ou implicitamente, têm embasado muitos projetos de cidadania, modelado concepções do que significa ser cidadão e fundamentado distinção entre cidadãos reais, potenciais, problemáticos e impossíveis" (Rose, 2013 , p. 190). O autor pontua também que, até mesmo, a linguagem utilizada pelos “cidadãos biológicos" ganha um colorido biologizante (Rose, 2013, p. 200). Essa é uma realidade perceptível no contexto do HIV/aids. Termos como CD4 e carga viral, além da autodeterminação de "indetectável", como um objetivo a ser alcançado, foram utilizados em todas as narrativas deste estudo, reforçando o imperativo do autocuidado. Um único posicionamento crítico a respeito desse ponto surgiu na narrativa de uma das jovens entrevistadas ligada à militância:

A gente é tratado como carga viral, não é? Ah, não te falei, mas vou te falar agora. A gente é tratado em todos os espaços como carga viral, né? A gente só tem importância pela carga viral, por exemplo, assim, a gente vai no médico, o médico está preocupado com você ou só te julga se a carga viral tiver maior ou menor, o CD4, em si, que é ligado à saúde, bulhufas. 
Então, a gente sempre é carga viral. Para UNAIS, pra ONU, pro Departamento, a gente precisa só estar abaixo do detectável, precisa estar indetectável, se a gente estiver acima, a gente é um problema, se a gente tiver abaixo a gente não é um problema. Então, está todo mundo medicalizado e indetectável, a gente não é mais um problema, mas, a gente precisa fazer o problema. Então, é isso, assim, eu acho que as pessoas também... o mal do brasileiro é... é a gente não muda por nada e a gente tá aí desse jeito. (Rafaela, 26 anos, diagnosticada há 24 anos)

Entre ditos e não ditos, presentes nas narrativas das/dos jovens, é possível apreender que suas vidas abrangem questões que vão além das variáveis biológicas identificadas como determinantes de saúde/doença. A vida de jovens com HIV/aids está imersa em um cenário composto por vivências de contornos complexos, que entrelaçam o pessoal e o social e, diante do exposto, entende-se que a comunicação e a circulação de informações sobre jovens com HIV/aids ainda são um desafio.

\section{AS NARRATIVAS FICCIONAIS}

O mapeamento dos temas frequentes e dos selves preferenciais, identificados a partir da análise das entrevistas, serviram de base para a construção de um texto em forma de narrativa ficcional. As interações e diálogos com os participantes, as colaborações, indicação de vetos, cortes e alterações colocaram em evidência elementos do viver com HIV/aids que constituem as experiências de jovens soropositivos/as, sinalizando que histórias são legitimadas pelos/as participantes do estudo e constituem-se como pontos de resistência. A seguir, apresentamos uma narrativa ficcional construída como produto de pesquisa.

Dois de mim

Desde o início eram dois. A mãe chamava: João, vem aqui. E lá iam os dois, João e Vicente. Sempre juntos, de tão grudados, pareciam um só. E assim a vida corria, tranquila, eles nunca se sentiam sozinhos.

A cidade era pequena, os dias passavam sossegados. Tinha hora para tudo, acordar, ir para a escola, estudar, brincar, hora para dormir. Não se falava muito do "mundo lá fora" e os dois amigos, companheiros e confidentes, se bastavam.

Enquanto João e Vicente cresciam, as famílias mudaram um pouco. Uns casaram, outros se afastaram, quando João estava com 10 anos, sua mãe morreu. Naquele dia, Vicente, abraçou forte o amigo. 
Os anos passaram e por volta dos 14 ou 15, Vicente começou a perceber que o mundo não era tão pequeno quanto o lugar onde ele havia crescido. Nessa época, pelo computador, começou a conhecer outros mundos, passou a desejar a "cidade grande".

A partir daquele momento, aquelas eram as conversas e os sonhos. Vicente falava para João sobre as festas, as boates, planejava como os dois iriam se divertir e conhecer pessoas novas. Como Vicente queria que aquele dia chegasse!

Quando fizeram 18, Vicente até que procurou emprego por ali, mas não conseguiu e decidiu que era hora de ir. Estava feliz, finalmente chegara o dia de viver tudo o que até aquele momento ficava apenas na imaginação. João, notou que não queria tanto partir e decidiu ficar. Os dois se despediram. Vicente foi buscar sua independência e, naquele dia, João abraçou forte o amigo.

Assim foi. De repente, para Vicente era tudo diferente. Tanta gente, movimento, liberdade, não precisava dizer a hora de ir ou de voltar. A primeira vez que saiu à noite se assustou. Ficou ali, no canto, sozinho, a observar. Mas alguma coisa o encantou e ele quis voltar.

Passeava, conhecia lugares novos, trabalhava. Afinal, tinha que se sustentar. Em pouco tempo, passou a gostar das festas. No início ainda era quieto, meio tímido. De vez em quando ainda falava com João. Depois, fez novos amigos, conheceu outros meninos, sentia que aproveitava a vida.

Durante um tempo, era assim que vivia, sem se preocupar. Saía, se divertia, às vezes, fazia sexo sem se cuidar, porque bebia um pouco demais e esquecia a camisinha, ou porque achava que não precisava, ou porque os caras diziam que não tinham nada. Até que começou a namorar. Foram morar juntos. Vicente ainda saía, mas não ia mais a tantas festas, voltou a conversar mais com João.

Um dia Vicente adoeceu. Muito rápido, emagreceu, muito. Era uma coisa diferente a cada dia. Infecção urinária, infecção pulmonar, era difícil respirar. Ia ao médico e lá no fundo da cabeça, começou a desconfiar que podia ser aids. Mas tinha medo, muito medo de fazer o teste. Até que não teve jeito, certa manhã, não conseguiu caminhar; mal podia se levantar. Teve que ir para o hospital, de pronto foi internado. Pediram sua autorização para fazer o teste e Vicente disse que sim. Naquele dia, ele chorou.

Uma semana se passou. Era sábado de manhã, o médico entrou e confirmou, era HIV e a infecção estava em um estado muito avançado. Talvez, se Vicente tivesse demorado mais um pouco para ir ao hospital, não teria aguentado, teria morrido.

No momento da notícia, não ficou desesperado. Tinha dúvidas, medos, mas durante aqueles cinco dias, à espera do resultado, ele pesquisou tudo o que pôde. Encontrou alguém que viveu as mesmas coisas, conversou e guardou um conselho recebido: toma seu remédio e vive sua vida!

Com o tempo, Vicente melhorou, saiu do hospital e voltou para casa. Viveu dias difíceis até se recuperar, estava fraco, a imunidade muito baixa, ainda não podia sair, não podia trabalhar. Quando sentiu que estava bem, chamou João para conversar e contou tudo o que viveu. João estava feliz de ver o amigo ali, vivo. 
Os dois saíram para passear. Vicente apresentou a cidade, João ficou encantado com o que viu. Se não fosse o Vicente, ele nunca teria saído do lugar onde nasceu. Vicente também estava feliz. Estar com João o fazia se lembrar de quando a vida era um pouco mais tranquila. E naquele dia os dois se abraçaram, novamente pareciam ser apenas um. Na verdade, eles eram só um!

Essa é a história de João Vicente. Um menino que sempre teve um lado mais quieto, outro mais agitado. Um lado tinha medo de se lançar na vida, e refletia tanto que no fim nada fazia, o outro queria beber o mundo em um gole só! Naquele abraço, que juntou as duas partes, de quem sempre havia sido só um, João Vicente sentiu que não precisava se separar em dois, que seria bom viver com suas duas partes. E João Vicente seguiu, fazendo escolhas, vivendo a vida!

De vez em quando, tudo o que João Vicente queria era um dia, pelo menos um dia, não lembrar de HIV, de aids. Ele pensa: já tem as contas para pagar, os estresses do dia a dia, que às vezes, tudo que ele queria era viver sem pensar na hora, no remédio, no comentário que alguém pode soltar...

A história exibe um dado presente nas narrativas de alguns entrevistados a migração de jovens oriundos de cidades pequenas para cidades grandes - $\mathrm{o}$ que nas narrativas foi associado à curiosidade, à empregabilidade e, no caso dos homossexuais, também ao desejo de viver a sexualidade de forma livre. Essa narrativa ficcional fala de expectativas e desafios, como o sustento financeiro envolvidos nesse movimento. O uso abusivo de álcool e a inconsistência do uso do preservativo nas relaçôes sexuais também é apresentado. $\mathrm{O}$ temor relacionado ao exame de HIV foi tema presente nas entrevistas narrativas e incluído no texto, assim como o adoecimento por aids. O tratamento através da medicação é abordado e, ao final, o HIV surge como um elemento da vida paralelo a outras questóes confrontadas no cotidiano. Essa narrativa discorre sobre aspectos que englobam o período anterior e posterior à infecção, ponto realçado pelos jovens que afirmaram desejar falar de outros temas de suas vidas além da infecção pelo HIV. Os temas recortados das entrevistas realizadas e presentes nessa narrativa ficcional, de certo modo, se aproximam daqueles explorados pelo estudo de Sehneme et al(2015). Em sintonia com os autores, as narrativas destacadas nesta pesquisa oferecem visibilidades específicas sobre as nuances do viver com HIV/ aids entre pessoas jovens.

\section{CONSIDERAÇŌES FINAIS}

Não é incompreensível que, no início da epidemia, os termos HIV e aids fossem tomados como sinônimos, pois a infecção pelo HIV era, na maioria das vezes, atrelada ao quadro de adoecimento por aids, trazendo a reboque o 
cenário de discriminação, isolamento e, em muitos casos, morte. A chegada dos antirretrovirais, no ano de 1996, possibilitou mudanças relativas ao tratamento e expectativa de vida de pessoas vivendo com HIV/aids.

Entretanto, parte do imaginário social segue cristalizado em realidades do início da epidemia, fazendo com que, ainda hoje, o medo e o preconceito estejam presentes quando se fala em HIV. É nesse contexto de contradições em que estão inseridos os jovens que no momento vivem com HIV ou aids. Conforme nos fala Cunha (2011), eles são os representantes da "aids feliz e de um nível educado de dor" (Cunha, 2011, p. 4).

As aproximações com o campo empírico da pesquisa proposta, a partir de observações dos participantes e das narrativas construídas com as/os jovens que vivem com HIV, trouxeram a identificação de que o viver com HIV/aids, para eles, acarreta um conjunto de (re)adaptações cotidianas, que envolve a relação com seus corpos, seus pares, suas famílias e sua sexualidade.

Levantamos aqui a importância de buscar maneiras de contribuir para a ampliação do conhecimento sobre a multiplicidade de formas de viver com HIV/aids na atualidade, posto que a dificuldade de revelação do diagnóstico, em função do receio da rejeição, também contribui para a manutenção do preconceito oriundo do medo e do desconhecimento. Diante disso, as narrativas ficcionais se mostraram como uma interessante alternativa para que se possa divulgar histórias sobre o cotidiano de jovens que vivem com HIV e experimentar formas de dialogar com esse público. Constituiu-se um desafio, em particular, disseminar informaçôes sobre o viver com HIV/aids e incluir a perspectiva da prevenção sem reproduzir discursos moralizantes. Nesse sentido, o direcionamento recaiu sobre o objetivo de transformar experiências humanas em histórias a partir das narrativas, pois compreendemos que, quando os jovens se identificam com determinados pontos, eles podem engendrar reflexões sobre suas escolhas e trajetórias de vida.

Há que se ter especial atenção à uniformização dos discursos acerca do viver com HIV/aids, levando em conta que isso pode reduzir as possibilidades de um diálogo amplo e limitar a compreensão do de seu cotidiano e de suas singularidades. Os jovens entrevistados relataram vidas que seguem com expectativas, desejos, prazeres, diversão e angústias. Uma "vida normal" que não é sinônimo de vida sem conflitos ou desafios. Acredita-se que a construção de narrativas de vida de jovens que vivem com HIV/aids e o exercício de trazer a público suas histórias contribuirá para questionar práticas que recriam posturas excludentes e discursos naturalizantes sobre esses jovens, além de colaborar para ampliar reflexões acerca das práticas de prevenção e promoção da saúde. 


\section{REFERÊNCIAS}

Ayres, J. R., França Júnior, I., Calazans, G. \& Saletti, F. H. (2000). Vulnerabilidade e prevenção em tempos de Aids. In R.M., Barbosa \& R. Parker, (Orgs.) Sexualidades pelo avesso. (pp. 49-73). São Paulo: Editora 34.

Baldin, N. \& Munhoz, E. (2011). Snowball (bola de neve): uma técnica metodológica para pesquisa em educação ambiental comunitária. Anais, 10 Congresso Nacional de Educação - Educere. Curitiba.

Baptista, C. J., Maciel, A. G., Caldeira, A.P., Tupinambás, U., Greco, D.B. (2012). Prevalência de fatores de vulnerabilidade juvenil às DST/ HIV/ AIDS: estudo com enfoque de gênero no Norte de Minas Gerais, Brasil, 2008-2009. Motricidade, 8(S2),1-Recuperado a partir de http://www.redalyc.org/articulo. oa?id=273023568021 > ISSN 1646-107X

Brasil. (2015). Ministério da Saúde. Secretaria de Vigilância em Saúde. Departamento de DST, Aids e Hepatites Virais. Boletim Epidemiológico HIV. AIDS.

Cogan, D. (Produtor), \& France, D. (Diretor). (2012). How to Survive a Plague [Filme]. EUA: Mpi home video.

Cunha, C. (2011) "Jovens vivendo" com HIVIAIDS: (Con)formação de Sujeitos em meio a um embaraço. (Tese de Doutorado). Universidade Federal do Rio de Janeiro, PPGAS/MN, Rio de Janeiro.

Cunha, C. (2012). Os muitos reveses de uma "sexualidade soropositiva": o caso dos jovens vivendo com HIV/AIDS. Sexualidad, Salud y Sociedad, 10, 70-99. Recuperado a partir de https://dx.doi.org/10.1590/S198464872012000400004

Galvão, J. (2000). Aids no Brasil: a agenda de construção de uma epidemia. São Paulo: Editora 34/ABIA.

Greco, D. B. (2016). Trinta anos de enfrentamento à epidemia da Aids no Brasil, 1985-2015. Ciência \& Saúde Coletiva, 21(5), 1553-1564. Recuperado a partir de https://dx.doi.org/10.1590/1413-81232015215.04402016

Jovchelovitch, S \& Bauer, M. W. (2007). Entrevista narrativa. In M. W., Bauer, \& G. Gaskell (Eds.). P. A., Guareschi, (Trad.). Pesquisa qualitativa com texto, imagem e som: um manual prático (6a ed.) (pp. 90-113). Petrópolis, RJ: Vozes. 
Leavy, P. (2013). Blurred Genres: the intertwining of fiction and nonfiction. In P. Leavy. Fiction as Research Practice. Short Stories, Novellas, and Novels. New York: Left Coast Press.

Mann, J. (1987, 20 Octuber). Statement at an informal briefing on AIDS to the 42nd Session of the United Nations General Assembly, New York: APPS. Recuperado a partir de http://apps.who.int/iris/handle/10665/61546

Nelson, A., Silva, R., Duarte, F., Prado, N., Costa, D., \& Holanda, J. (2016). Conhecimento de estudantes adolescentes sobre transmissão, prevenção e comportamentos de risco em relação às DST/HIV/ AIDS Adolescentstudentsknowledgeabouttransmition, prevention andriskybehaviorrelatedto STD/HIV/AIDS. Revista de Pesquisa: Cuidado é Fundamental Online, 8(4), 5054-5061. Recuperado a partir de doi:http:// dx.doi.org/10.9789/2175-5361.2016.v8i4.5054-5061

Organização Mundial de Saúde (2003). Cuidados inovadores para condiçôes crônicas: componentes estruturais de ação: relatório mundial. Brasília: OMS. Recuperado a partir de Disponível em: http://www.who.int/chp/knowledge/ publications/icccportuguese.pdf

Organização das Nações Unidas (2016, June). Political Declaration on HIV and AIDS: On the Fast-Track to Accelerate the Fight against HIV and to End the AIDS Epidemic by 2030. Recuperado a partir de http://www.unaids.org/sites/ default/files/media_asset/2016-political-declaration-HIV-AIDS_en.pdf.

Parker, R. \&Aggleton P. (2001). Estigma, discriminação e Aids. Rio de Janeiro: Coleção ABIA: Cidadania e Direitos Associação Brasileira Interdisciplinar de Aids. Recuperado a partir de http://www.abiaids.org.br/_img/media/ colecao\%20cidadania\%20direito.pdf

Pereira, B., Costa, M., Amaral, M., Costa, H., Silva, C., \& Sampaio, V. (2014). Fatores associados à infecção pelo HIV/AIDS entre adolescentes e adultos jovens matriculados em Centro de Testagem e Aconselhamento no Estado da Bahia, Brasil. Ciência \& Saúde Coletiva, 19(3), 747-758. Recuperado a partir de https://dx.doi.org/10.1590/1413-81232014193.16042013

Programa das Nações Unidas sobre HIV/AIDS 2016). 90-90-90 Uma meta ambiciosa de tratamento para contribuir para o fim da epidemia de AIDS. http://unaids.org.br/wp- Recuperado a partir de content/ uploads/2015/11/2015_11_20_UNAIDS_TRATAMENTO_META_PT_ v4_GB.pdf Reigota, M. (1999). Ecologistas. Santa Cruz do Sul: EDUNISC. 
Ribeiro, A. Padoin, S., Paula, C \& Terra, M. (2013, Julho, Setembro). O cotidiano do adolescente que tem HIV/aids: impessoalidade e disposição ao temor. Texto Contexto Enferm, Florianópolis, 2013 22(3), 680-6 Disponível em: Recuperado a partir de http://www.scielo.br/pdf/tce/v22n3/v22n3a14.pdf

Rios, L., Pimenta, C., Brito, I., Terto Júnior, V., \& Parker, R. (2002). Rumo à adultez: oportunidades e barreiras para a saúde sexual dos jovens brasileiros. Cadernos CEDES, 22(57), 45-61. Recuperado a partir de https://dx.doi. org/10.1590/S0101-32622002000200004.

Riessman, C. K. (2008). Narrative methods for the human sciences. California: Sage. Rose, N. (2013). A politica da própria vida: biomedicina, poder e subjetividade no Século XXI. In P. Valério (Trad.). São Paulo: Paulus.

Sehnem, G., Brondani, J., Kantorski, K., Silva, S., Ressel, L., \& Pedro, E. (2015). A saúde no adolescer com HIV/aids: caminhos para uma agenda pós2015. Revista Gaúcha de Enfermagem, 36(spe), 39-46. Recuperado a partir de https://dx.doi.org/10.1590/1983-1447.2015.esp.57385

Squire, C. (2010). Being naturalised, being left behind: the HIV citizen in the era of treatment possibility. CriticalPublic Health, 20, 401-427. Recuperado a partir de DOI: https://doi.org/10.1080/09581596.2010.517828

Tamboukou, M. (2016). Aventuras da pesquisa narrativa. In L., Kind \& R., Cordeiro. (Orgs.). Narrativas, gênero e politica. Curitiba: CRV.

Val, L. F. do, Silva, J. A. de, Souza, R. L. A., Lima, R. H. dos, Anjos, B. R. L., \& Nichiata, L. Y. (2013). Estudantes do ensino médio e o conhecimento em HIV/AIDS: que mudou em dez anos?. Revista da Escola de Enfermagem da USP, 47(3), 702-708. Recuperado a partir de https://dx.doi.org/10.1590/ S0080-623420130000300025 